Original Article

\title{
Assessment of deep catastrophic landslides susceptibility to earthquake
}

\author{
Nagazumi TAKEZAWA ${ }^{1}$, Taro UCHIDA ${ }^{2}$, Osamu YOKOYAMA ${ }^{1}$, Keiji TAMURA $^{3}$ \\ Tadanori ISHIZUKA ${ }^{1}$, Keisuke SUZUKI $^{4}$ and Masakatsu MIYAJIMA ${ }^{5}$ \\ ${ }^{1}$ Public Works Research Institute (1-6, Minamihara, Tsukuba, Ibaraki 3058516, Japan) \\ E-mail: takezawa@pwri.go.jp \\ 2 National Institute for Land and Infrastructure Management (1, Asahi, Tsukuba, Ibaraki 3050804, Japan) \\ 3 Unzen Restoration work office (7-4, Minami-shimokawajiri-machi, Shimabara, Nagasaki 8550866, Japan) \\ 4 Iwate office of River and National Highway (4-2-2, Ueda, Morioka, Iwate 0200066, Japan) \\ 5 University of Kanazawa (Kakuma, Kanazawa, Ishikawa 9201192, Japan)
}

\begin{abstract}
In steep mountainous regions, landslides may include both soil and underlying weathered bedrock (hereafter, "deep catastrophic landslides"). The method for assessing susceptibility to deep catastrophic landslides, originally developed for landslides caused by heavy rain, was tested in this study against historical landslides caused by the Iwate and Miyagi inland earthquake of 2008. The method proved to be capable of independently identifying catchments in which deep catastrophic landslides occurred with fair accuracy.
\end{abstract}

Key words: deep catastrophic landslide, earthquake-induced landslide, fault distance, geological structures and landforms, landslide scar

\section{INTRODUCTION}

Earthquakes, like heavy rains, may cause landslides and endanger life and property. A number of previous studies have been examined roles of seismic force, geology and topography in earthquake-induced landslides occurrence [e.g., Keefer, 1984, Saito et al., 1995 Harp et al., 1996]. According to these studies, a number of empirical methods have been proposed [e.g., Uchida et al., 2006; Lee et al., 2006; Lee et al., 2008; Miles et al., 2009]. Also, several physical models for assessing seismic landslide susceptibility have been applied [e.g., Mankelow et al., 1998; Carro et al., 2003; Jibson., 2007].

Landslides may include not only soils but also underlying weathered bedrock (hereafter, "deep catastrophic landslides" or DCLs). Such landslides are large-scale phenomena that can result in disasters caused by large debris flow or landslide dams [Earthquake spectra, 2001; Yagi et al., 2009; $\mathrm{Ou}$ et al., 2010]. To mitigate damage due to seismically induced sediment-related disasters, it is important to identify potential sites of DCLs and undertake control measures. However, most previous studies of seismic landslide susceptibility dealt mainly with shallow landslides. So, to date there is no established method for evaluating the susceptibility of earthquake-induced DCLs.

Uchida et al. [2011] developed a method for assessing susceptibility to DCLs for one-square-kilometer catchments over relatively large areas (several hundred square kilometers), using data on ancient DCL scars, distribution of geological structures and landforms, and topography. They also showed that sites of heavy rain-induced DCLs were predicted with high accuracy using their method. The applicability of this method to earthquake-induced DCLs has not yet been tested.

A difference in topographic effect on landslide occurrence between rainfall-induced and earthquake-induced DCL have been examined. Chang et al. [2000] and Meunier et al. [2007] determined that rainfall-triggered landslides tended to be located at the area near stream channels, whereas earthquake-triggered landslides tended to be located at the area near ridge lines. Geli et al., 
[1988] argued that the spatial distribution of earthquake-triggered landslides was influenced by the amplification effect of topography. They showed that seismic motion was amplified near mountain tops, although the spatial distribution of rainfall-triggered landslides was strongly controlled by the behavior of groundwater [e.g., Okimura et al., 1985]. These suggests that the method proposed by Uchida et al. [2011] may be ineffective for evaluating the susceptibility of earthquake-induced DCLs

Meanwhile, several landforms induced by long-lasting mass movement (i.e., mass rock creep. chronic landslide etc.) and geological structures, likes active fault, geological fault, are commonly found around the both rainfall-induced DCL [Suzuki et al., 2007; Yokoyama et al., 2011] and earthquake-induced DCL [Yagi et al., 2009; Wang et al., 2003]. This suggests that the method proposed by Uchida et al. [2011] may be applicable for evaluating the susceptibility of earthquake-induced DCLs. Thus, to propose appropriate methods for evaluating the susceptibility of earthquake-induced, we verified the applicability of Uchida et al. [2011]'s method for assessing DCL susceptibility to earthquake-induced DCLs.

\section{METHOD}

\subsection{Outline of the method}

This method (Fig. 1) addresses landslide susceptibility in individual catchments in study areas with similar geological and climatic conditions. The assessment is made according to three criteria:

(A) Presence of preexisting DCL scars

(B) Presence of geological structures or landforms caused by long-term mass movements (creep)

(C) Presence of many steep slopes with large upslope contributing areas.

Criterion A is based on the fact that DCLs commonly develop near scars of previous DCLs [Suzuki et al., 2007; Takaya et al., 2007]. Criterion $\mathrm{B}$ is used because gravitational mass rock creep has been empirically linked to DCL [Chigira, 2006; Tamura et al., 2006]. Criterion C is known to contribute to shallow landslides and is also thought contribute to the development of DCLs. In the assessment method, it is assumed that susceptibility to DCLs increases with the number of criteria met..

\subsection{Features mapped (second box in Fig. 1)}

A map was created to illustrate the distribution of features associated with susceptibility to DCLs (Fig. 1, second box). Stereoscopic examination of aerial

\section{Determination of study area}

-Area under homogenous bedrock geology and climate condition was determined as the study area.

-Study area was divided into small catchments (area is around $1 \mathrm{~km}^{2}$ ), which evaluated land slide susceptibility

\section{Data preparation and mapping \\ -Aerial photograph, geological maps, DEM were prepared \\ - Based on the interpretation of aerial photographs, ancient deep catastrophic landslide scars and landforms were mapped. \\ -Slope angle and upslope contributing area were computed using DEM. \\ Preliminary analysis using historical data \\ -To determine detailed criteria, the relationship between old deep catastrophic landslide, landform, geological structures and topography were examined. \\ Assessing deep catastrophic landslide susceptibility \\ -Based on the determined criteria, the susceptibility of future deep catastrophic landslide in each catchment were assessed.}

Fig. 1 Flowchart of proposed method for assessing deep catastrophic landslide susceptibility
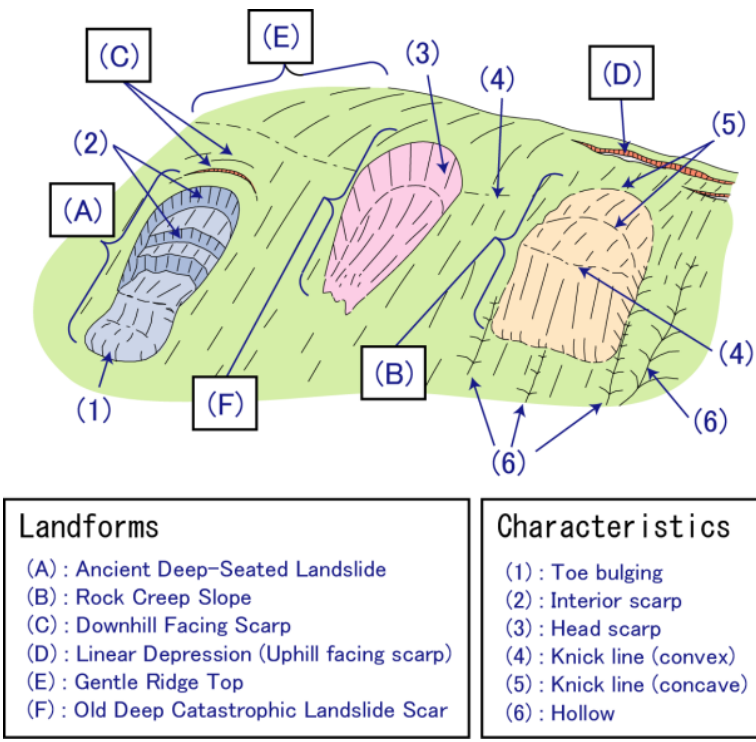

Char acter istics
(1): Toe bulging
(2): Interior scarp
(3): Head scarp
(4): Knick line (convex)
(5): Knick line (concave)
(6): Hollow

Fig. 2 Conceptual diagram of landforms related to deep catastrophic landslide (after Uchida et al. [2011])

photographs was used to construct a map-based inventory of DCLs. The inventory also included DCL scars depicted on existing geological maps, excluding their run-out zones.

Five landform types associated with long-lasting 
mass movement were identified on aerial photographs: Ancient Deep-Seated Landslides, Rock Creep Slopes, Downhill Facing Scarps, Gentle Ridge Tops, and Linear Depressions (Fig. 2). An existing geological map [National Institute of Advanced Industrial Science and Technology, 2010] was used to identify lineaments that could control DCLs. Slope angle and upslope contributing area for each mesh cell were calculated using a digital elevation model (DEM). All criteria were processed using global information systems software, including establishing a cell mesh on the map, creating polygon data for scars and landforms, and calculating slope angle and upslope contributing areas.

\subsection{Identifying indicators (third box in Fig. 1)}

In the assessment method, the relationships between geological structures, landforms and topography of old, DCL scars in the study area are analyzed (Fig. 1, third box) prior to considering geology and climate conditions (Fig. 1, fourth box).

\subsubsection{Geological structures and landforms}

The study area was divided into catchments with areas of approximately $1 \mathrm{~km}^{2}$. If the polygon for a given catchment overlapped with an old DCL polygon, the catchment was defined as an "old landslide catchment."

To clarify the roles of landforms and topography, two indices (normalized hit ratio [NHR] and cover ratio [CR], proposed by Yokoyama et al. [2011]) were used to quantify relationships among DCLs, landforms, and geological structures. Yokoyama et al. [2011] successfully quantify relationships between deep catastrophic landslides, landforms and geological structures. To analyze the relationship between past DCLs and geological structures and landforms, the NHR $\left(P_{i}\right.$, Eq. 1$)$ and the $\mathrm{CR}\left(C_{i}\right.$, Eq. 2) were calculated for each geological structure, landform, and old landslide, as follows:.

$$
\begin{gathered}
P_{i}=\frac{\frac{N_{L, i} / N_{i}}{N_{L} / N}}{C_{i}=\frac{N_{i}}{N_{L, i}}}
\end{gathered}
$$

where $N_{L, i}$ is the number of old landslide catchments containing landform or geologic structure $i, N_{i}$ is the number of catchments with landform or geologic structure $i, N_{L}$ is the total number of old landslide catchments in the study area, and $N$ is the total number of catchments in the

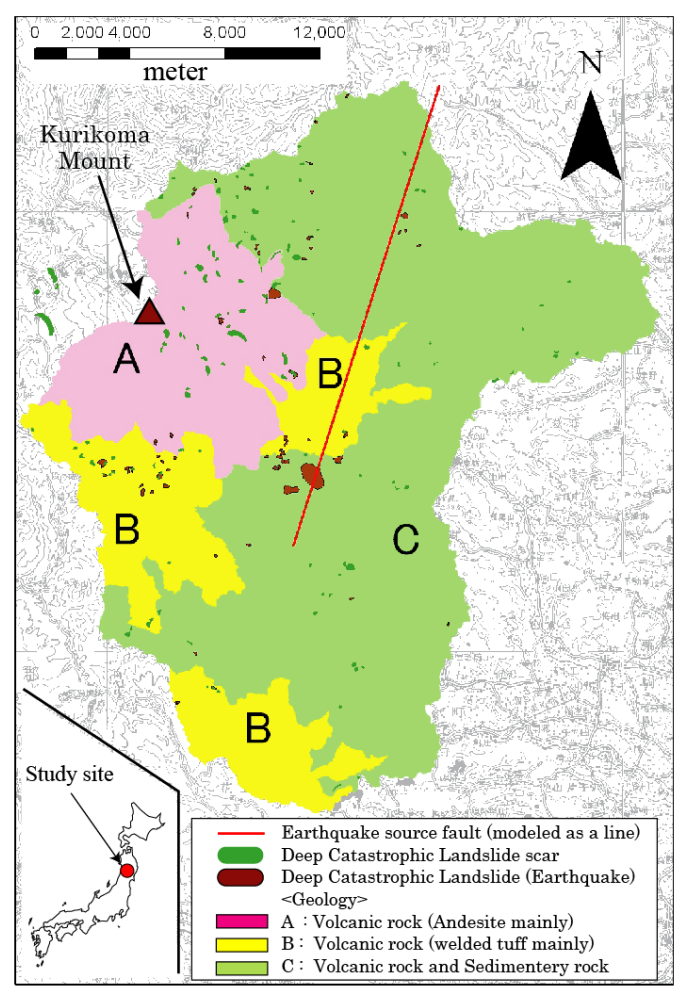

Fig. 3 Geological classification of study site

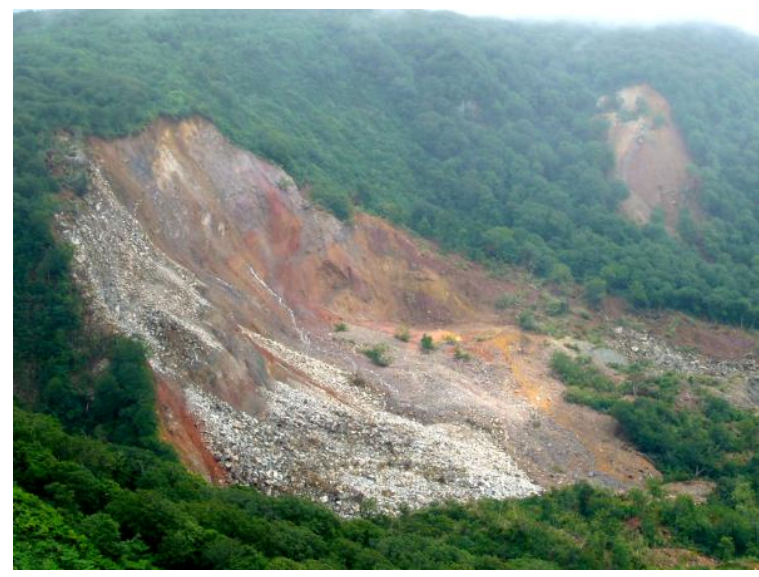

Photo 1 Deep catastrophic landslide(in Ubusume River)

study area.

Two geological structures or landforms for which a high NHR and a high CR can be obtained are selected. Then the NHR and CR obtained from different combinations of geological structures or landforms (AND/OR) are compared, and geological structures and landforms associated with DCL susceptibility are determined.

\subsubsection{Topography}

Local slope angle and upslope contributing area were calculated using the D8 method for a single flow direction procedure [O'Callaghan and Mark, 
1984]. Slope angle and upslope contributing area were classified into 72 categories. If the center of a given cell was within an old DCL polygon, it was defined as a "landslide cell." The landslide ratio was calculated as the ratio of landslide cells to the total number of cells in each topographic category. Then mesh cells containing a landslide cell more than two times more susceptible than the mean value (hereafter, "highly susceptible cells") were identified.

To analyze the relationship between the number of highly susceptible cells $(n)$ and old DCL scars, the relationship between $\mathrm{n}$ and the NHR $P(n)$ and CR C(n) were analyzed as follows:

$$
\begin{gathered}
P(n)=\frac{N_{L}(n) / N(n)}{N_{L} / N} \\
C_{i}=\frac{N_{L}(n)}{N_{L}}
\end{gathered}
$$

where $N(n)$ is the number of catchments with more than $\mathrm{n}$ highly susceptible cells and $N_{L}(n)$ is the number of old landslide catchments with more than $n$ highly susceptible cells. Finally, catchments with a large number of highly susceptible cells were designated "highly susceptible catchments".

\section{EARTHQUAKE AND STUDY SITE}

The study area (about $429 \mathrm{~km}^{2}$ ) included Mt. Kurikoma, Miyagi Prefecture (Fig. 3). The Iwate-Miyagi Inland earthquake of June 14, 2008, registered at a magnitude of 7.2 according to the Japan Meteorological Agency (JMA). In Kurihara City, Miyagi Prefecture, about $30 \mathrm{~km}$ south of the hypocenter, a seismic intensity of "6 Upper" was registered on the JMA scale.

This earthquake caused not only shallow landslides but also numerous DCLs (Photo 1) and landslide dams [Yagi et al., 2009]. Debris flows induced by DCLs caused seven deaths. Because landslide dams are often associated with subsequent outburst floods and debris flows, residents in the area had to evacuate the area for a long time.

The average temperature in the Mt. Kurikoma region is approximately $8^{\circ} \mathrm{C}$, and the annual mean precipitation is approximately $2,000 \mathrm{~mm}$. The elevation of the study area ranges from $\sim 50 \mathrm{~m}$ in the plain extending westward from Mt. Kurikoma to $1,627 \mathrm{~m}$ at the mountain top. There are gentle slopes and flatlands underlain by volcanic material, surrounded by scarps. The 2008 earthquake caused many landslides in this boundary zone. The area at the foot of Mt. Kurikoma is predominantly forested.
The bedrock of the Mt. Kurikoma area consists of Pleistocene (Quaternary) volcanic rocks. The summit of Mt. Kurikoma is composed of andesitic flows and pyroclastic flow deposits, and the area at the foot of the mountain is composed of welded tuff. These volcanic products, distributed around the summit of the mountain, are fringed by Miocene (Tertiary) rocks. The northern part of the fringe zone is underlain by volcanic rocks, the western part by siltstone, the southwestern part by interlayered sandstone and mudstone, and the south-southwestern part by andesite.

\section{DATA \& DATA ANALYSIS PREAMBLE}

\subsection{Zoning of study area}

The study area was divided into 353 catchments, each with an area of approximately $1 \mathrm{~km}^{2}$. Bedrock composition of the area (Fig. 3) was classified based on existing geological maps [National Institute of Advanced Industrial Science and Technology, 2010] as Type A (mainly andesite; about $74 \mathrm{~km}^{2}$ ), Type B (mainly tuff; about $85 \mathrm{~km}^{2}$ ), and Type C (sedimentary rocks or other volcanic rocks; about $271 \mathrm{~km}^{2}$ ).

\subsection{Data set}

To identify old DCL scars associated with events prior to the 2008 earthquake (hereafter, "Pre-LS"), aerial photographs (scale $1 / 16,000$ to $1 / 40,000$ ) taken in 1947, 2006, and 2007 were interpreted. Slopes denuded by DCLs and spoon-shaped concavities were identified, and those with an area greater than about $10,000 \mathrm{~m}^{2}$ were considered old DCLs. The timing and cause of pre-quake landslides were not determined.

The sites of post-quake DCLs were identified through the interpretation of aerial photographs (scale $1 / 8,000$ to $1 / 10,000$ ) taken in June and October, 2008. As in the identification of pre-quake DCL sites, landside sites with areas greater than about $10,000 \mathrm{~m}^{2}$ were considered post-quake (new) DCLs (hereafter, "Post-LS").

It is probable that the occurrence of earthquake-induced DCLs is affected by distance from the source fault. Of the four sides of the source fault [Geospatial Information Authority of Japan, 2008] of the Iwate-Miyagi Inland Earthquake, the side closest to the ground surface was projected to the ground surface, and the projection was modeled as a line. The distance from the center of each catchment to the source fault (hereafter, "fault distance classes") was classified into three ranges $(0-4 \mathrm{~km}, 4-8 \mathrm{~km}$, and $8-12 \mathrm{~km})$ and the number of catchments containing post-quake DCLs was 


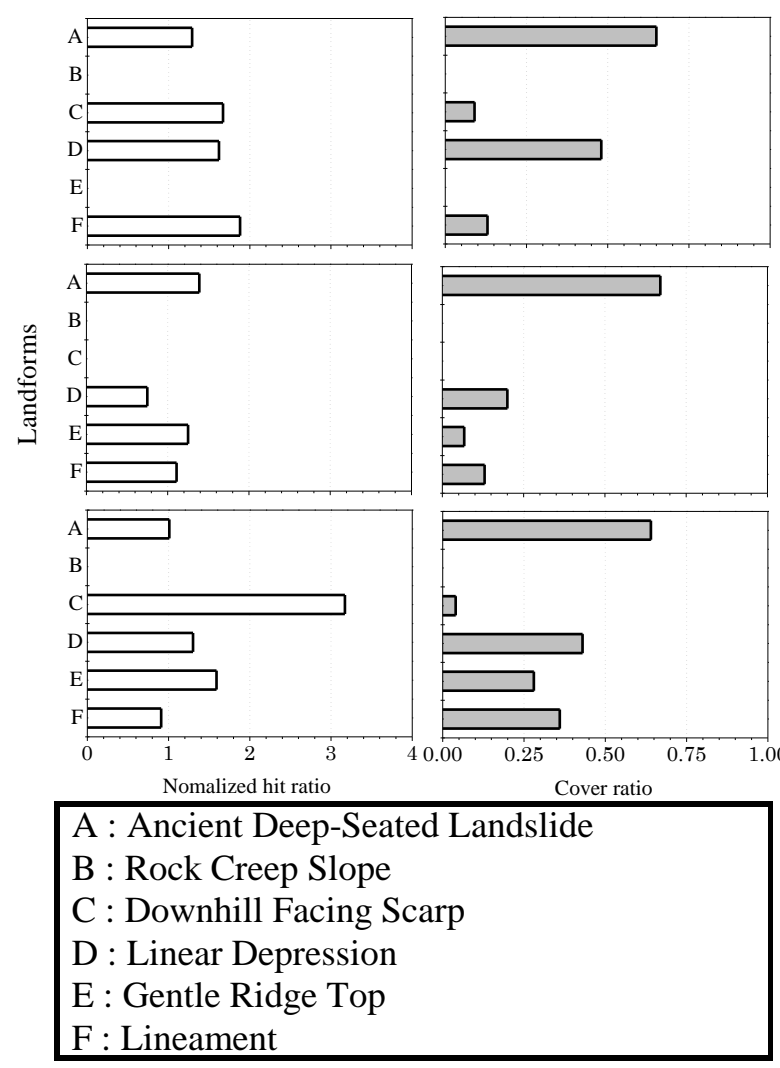

Fig. 4 Normalized hit ratio and cover ratio with respect to geological structure and landform indicators(top: Geology Type A, middle: Type B, bottom: Type C)

determined for each fault distance class.

Polygon data were produced for Pre-LS and Post-LS as identified by the means outlined above (Ancient Deep-Seated Landslide, Rock-Creep Slope, Downhill Facing Scarp, Linear Depression, Gentle Ridge Top, Lineament). Slope angle and upslope contributing area for each mesh cell were calculated using 50-m mesh digital elevation data provided by the Geospatial Information Authority of Japan.

\section{DETERMINATION OF CRITERIA}

\subsection{Past deep catastrophic landslides}

Aerial photograph interpretation identified 128 Pre-LS (85 catchments had at least one Pre-LS) and 67 Post-LS (51 catchments had at least one Post-LS).

\subsection{Relationship between Pre-LS and geological structures/landforms.}

According to the NHRs and CRs (Fig. 4; Table 1), the two landform types that are most closely related to DCLs were selected for each geology type: Linear Depression and Ancient Deep-Seated Landslide for Geology Type A, Lineament and Ancient Deep-Seated Landslide for Geology Type
Table 1 Normalized hit ratio (NHR) and cover ratio (CR) obtained from different combinations of geological structures or landforms

\begin{tabular}{|c|c|c|c|}
\hline $\begin{array}{c}\text { Geology } \\
\text { Type }\end{array}$ & $\begin{array}{c}\text { Geological structure or landforms } \\
\text { from long-lasting mass } \\
\text { movements }\end{array}$ & NHR & CR \\
\hline \multirow{2}{*}{ A } & $\begin{array}{c}\text { Linear Depression or } \\
\text { Ancient Deep-Seated Landslide }\end{array}$ & 0.49 & 0.78 \\
\cline { 2 - 4 } & $\begin{array}{c}\text { Linear Depression \& } \\
\text { Ancient Deep-Seated Landslide }\end{array}$ & 0.89 & 0.35 \\
\hline \multirow{2}{*}{ B } & $\begin{array}{c}\text { Lineament or } \\
\text { Ancient Deep-Seated Landslide }\end{array}$ & 0.29 & 0.80 \\
\cline { 2 - 4 } & $\begin{array}{c}\text { Lineament \& } \\
\text { Ancient Deep-Seated Landslide }\end{array}$ & 0.00 & 0.00 \\
\hline C & $\begin{array}{c}\text { Gentle Ridge Top or } \\
\text { Downhill Facing Scarp }\end{array}$ & 0.36 & 0.32 \\
\cline { 2 - 4 } & $\begin{array}{c}\text { Gentle Ridge Top \& } \\
\text { Downhill Facing Scarp }\end{array}$ & - & 0.00 \\
\hline
\end{tabular}

Table 2 Landslide ratios resulting from combinations of slope angle and upslope contributing area. Shaded categories represent less than $1 \%$ of all grid cells in the study area. Red line encloses highly susceptible topographic categories

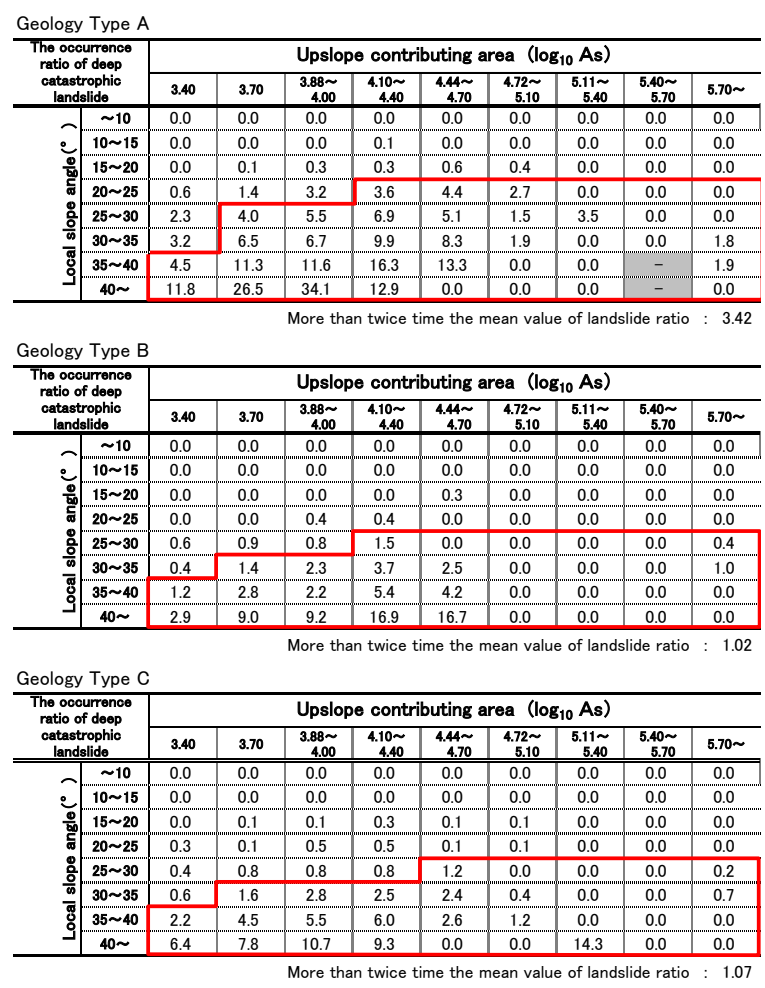

B, and Gentle Ridge Top and Downhill Facing Scarp for Geology Type C. Of the combinations of landforms in each geology type, landforms with high NHRs and high CRs were considered the most suitable indicators for each geology type. In this manner, highly susceptible catchments were 


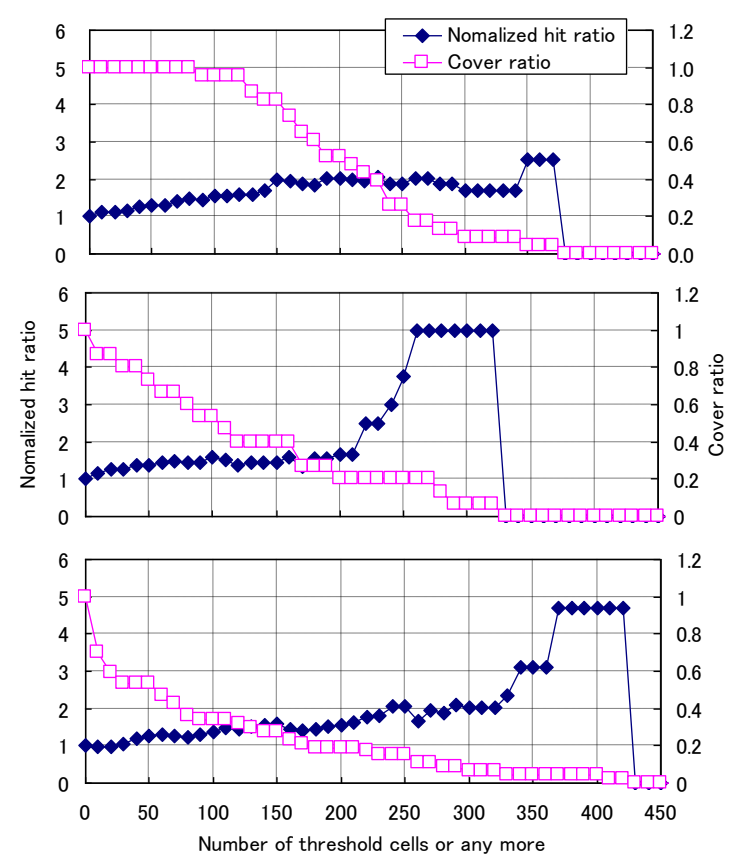

Fig. 5 Relationship between occurrence of deep catastrophic landslide and topography each geology type (top: Geology Type A, middle: Type B, bottom: Type C)

identified on the basis of landforms and geologic structures.

\subsection{Relationship between Pre-LS and topography}

The relationships between landslide ratio and different combinations of local slope angle and upslope contributing area for each geology type were determined (Table 2). The landslide ratio increased with both local slope angle and upslope contributing area. Highly susceptible cells were identified as those matching the categories outlined in red in Table 2. The relationship between the number of highly susceptible cells and the NHR and the CR for each catchments was established (Fig. 5). Catchments with 150 or more highly susceptible cells for Geology Type A, 100 or more highly susceptible cells for Geology Type B, and 150 or more highly susceptible cells for Geology Type C, were defined as highly susceptible to DCLs in terms of topography.

\section{RESULT}

As shown in Fig. 6, as the number of criteria satisfied increases, the number of catchments decreases; 189 catchments satisfied no criteria. DCLs caused by the Iwate-Miyagi Inland Earthquake of 2008 occurred in 13 of the catchments that satisfied no criteria. DCLs also occurred in 15 catchments that satisfies one criterion, 15 catchments that satisfied two criteria,

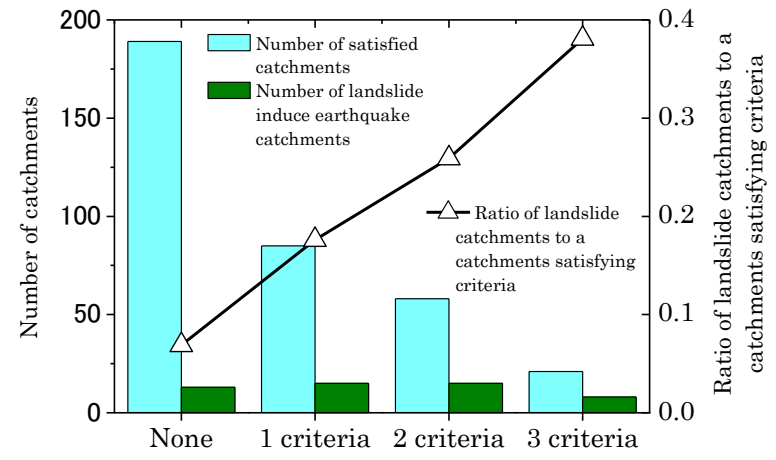

Fig. 6 Total catchments and earthquake-induced landslide catchments satisfying different numbers of susceptibility criteria and their ratios
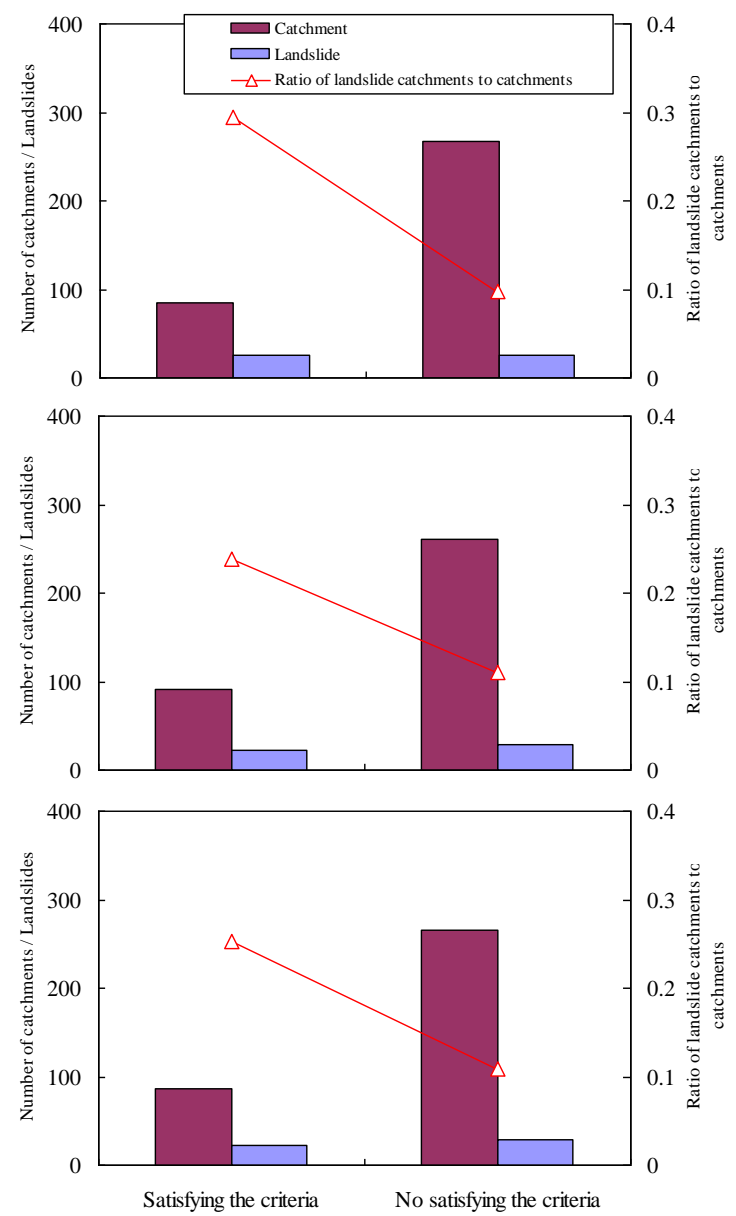

Fig. 7 The relationship between the occurrence of deep catastrophic landslides and satisfying the criteria (top: Pre-LS, middle: geological structure and landforms, bottom: topography)

and 8 catchments that satisfied three criteria. In addition, as the number of satisfied criteria increases, the percentage of catchments in which a DCL exists also increases. When the number of satisfied criteria was zero, the percentage of catchments in which at least one DCL exists was $6.9 \%$. When the number of satisfied criteria was 1 , 2 , or 3 , the percentage of catchments in which at 


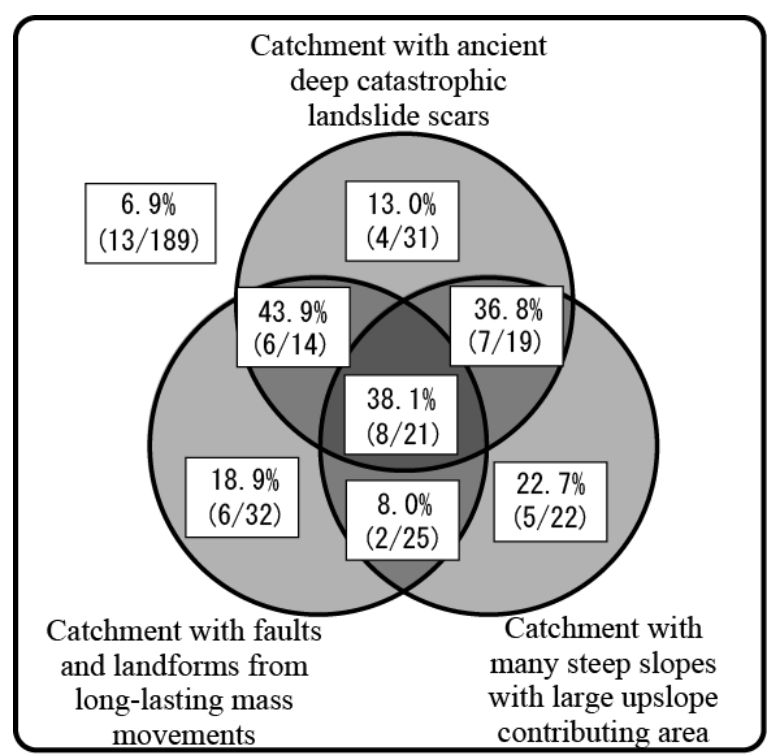

Fig. 8 The ratio of deep catastrophic landslide occurrence each criterion (in percent; formula for calculating the occurrence ratio in parentheses)

least one DCL exists was $17.6 \%, 25.9 \%$, and $38.1 \%$, respectively. This indicates that as the number of satisfied criteria increases by one, the percentage increases by a factor of $1.5-2.6$, demonstrating that this method for assessing DCL susceptibility can be used for catchment-by-catchment assessment of the relative susceptibility to earthquake-induced DCLs.

\section{DISCUSSION}

\subsection{Role of each criterion in the assessment of catchment susceptibility to earthquake-induced DCLs}

Fig. 7 shows the number of catchments that satisfy each criterion, the number of catchments that do not satisfy each criterion, the number of catchments among the latter in which at least one Post-LS exists, and their ratios. Among the catchments with Pre-LS, $29.4 \%$ had at least one Post-LS. In contrast, among those without Pre-LS, 9.7\% had at least one Post-LS. Among the catchments that satisfied the geological structure/landform criteria, $23.9 \%$ had at least one Post-LS. Among those that did not satisfy the criteria, $11.1 \%$ had at least one Post-LS. Similarly, $25.3 \%$ of catchments that satisfied the topography criteria had at least one Post-LS, whereas only $10.9 \%$ of catchments that did not satisfy the criteria had at least one Post-LS. In summary, 23.9-29.4\% of catchments that satisfied at least one criterion had at least one Post-LS, whereas $9.7-11.1 \%$ of those that did not satisfy any criteria had at least on Post-LS, indicating that there is very little
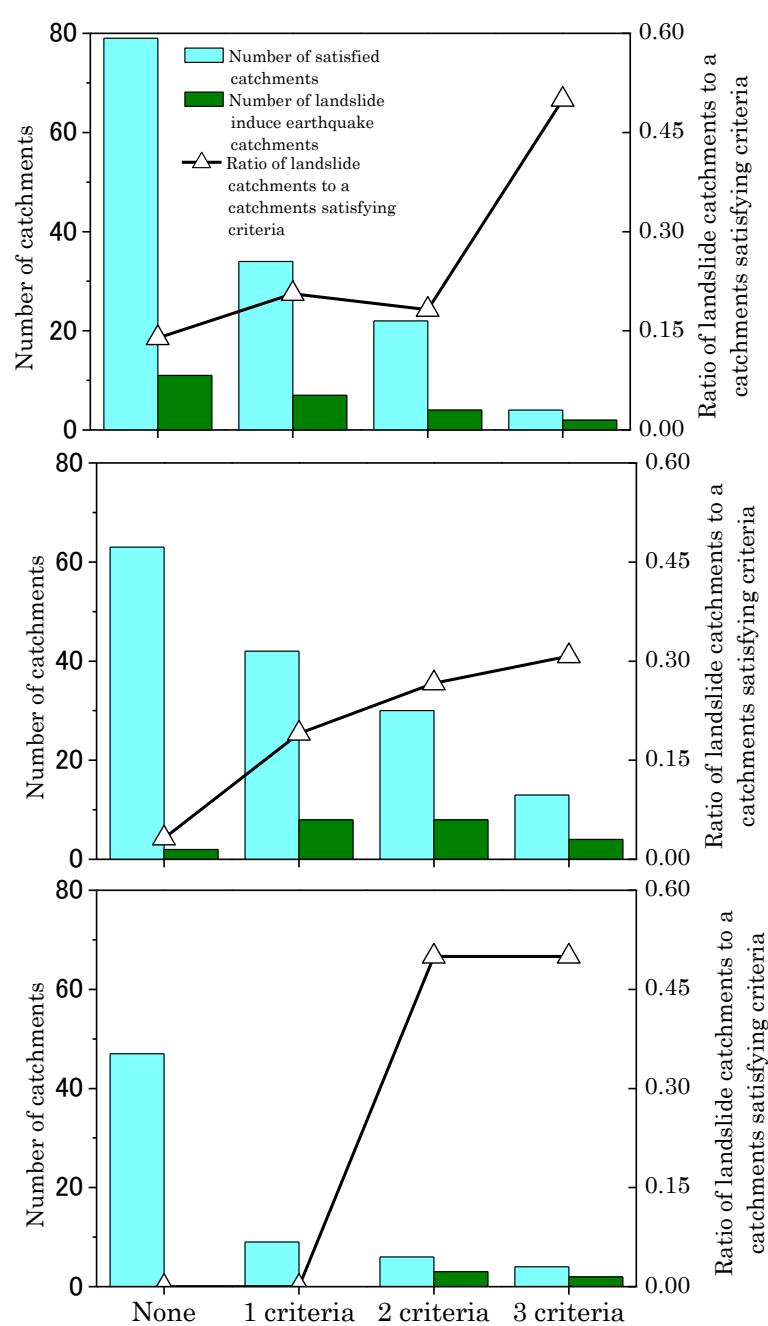

Fig. 9 Total catchments and earthquake-induced landslide catchments satisfying different numbers of susceptibility criteria and their ratios each fault distance classes (top: fault distance classes is $0-4 \mathrm{~km}$, middle: $4-8 \mathrm{~km}$, bottoms: $8-12 \mathrm{~km})$

difference, regardless of criteria.

Fig. 8 shows the ratio of DCL occurrence for each criterion. Of the catchments with at least one Post-LS, 13.0-22.7\% satisfied only one criterion. Thus, although there are differences depending on the criterion, in all cases the percentages are higher than those in the catchments that satisfied no criteria. Of the catchments that satisfied two criteria, 8.0-43.9\% had at least one Post-LS, depending on the combination of criteria. In all cases, however, the percentage is higher than in the catchments that satisfied no criteria. Among the catchments that satisfied all criteria, $38.1 \%$ had at least one Post-LS. Among the criteria, three appear to be particularly useful for improving the accuracy of identifying susceptible catchments: ancient DCL scar, geological structures/landforms, and topography.

Determining each factor's contribution to 
earthquake-induced landslide susceptibility requires independent assessment of each factor (e.g., geology, topography, seismic intensity), which is difficult [Hayashi et al., 2010]. Iwahashi et al. [2010] determined that the most suitable window size for a topographic index in the assessment of landslide susceptibility is proportional to the mean size of the target landslide. In this study, the window size for slope angle and upslope contributing area was a 50-m grid cell. The most suitable window size should be verified to increase the accuracy of assessment

\subsection{Effect of fault distance on the assessment of DCL susceptibility}

Fig. 9 shows the relationships between the number of satisfied criteria and the number of catchments, the number of catchments in which a post-quake landslide occurred, and the ratio of the number of catchments in which an earthquake-induced landslide occurred to the number of catchments, divided according to fault distance class. Regardless of fault distance, as the number of satisfied criteria increases, the ratio of the number of catchments in which there is at least one Post-LS to the number of criteria-satisfying catchments increases. For the fault distance class of 0-4 km, however, as the number of criteria increases from 1 to 2 , the occurrence ratio decreases from 0.21 to 0.18 . Of the catchments that did not satisfy any criteria, 11 had at least one Post-LS for fault distances of 0 to $4 \mathrm{~km}$, whereas 2 did for fault distances of 4 to $8 \mathrm{~km}$, and 0 did for distances greater than $8 \mathrm{~km}$. Note the decreasing trend. Similarly, the ratio of DCL occurrence decreased with increasing fault distance, both in catchments that did not satisfy any criteria as well as within any given criteria-satisfying catchment.

Uchida et al. [2011] showed that heavy rain-induced DCLs did not occur in catchments that did not satisfy any criteria. However, the present study reveals that a post-earthquake DCL occurred in 13 such catchments. The fact that $85 \%$ (11 catchments) of these 13 catchments were located $\leq 4$ $\mathrm{km}$ from a fault suggests that DCLs may occur in catchments with seemingly low DCL susceptibility because of very strong ground motion in the immediate vicinity of a fault. In other words, this assessment method is less accurate when very strong motion is involved. Furthermore, when the distance from a fault is $\leq 4 \mathrm{~km}$, the DCL occurrence ratio is high in catchments that satisfy a larger number of criteria. Therefore, the relative susceptibility to DCLs can be estimated under conditions of very strong ground motion.

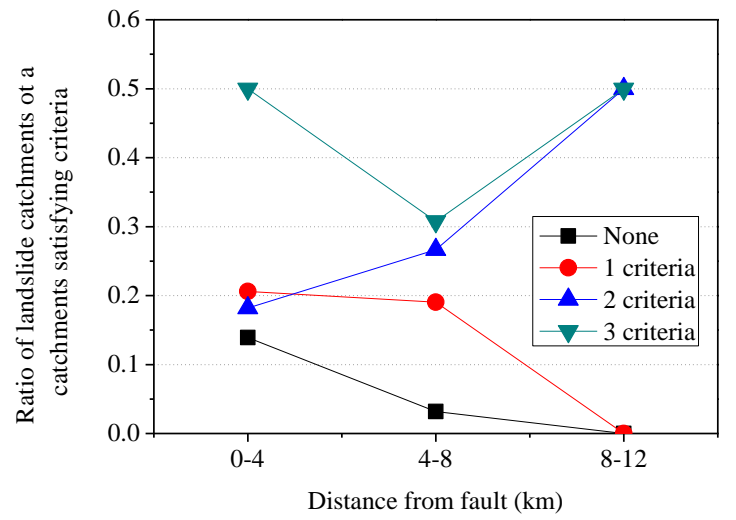

Fig. 10 Influence of distance from fault distance on relationship between the ratio of deep catastrophic landslides and the number of satisfied criteria

Fig. 10 shows the relationships among distance from a fault, number of criteria-satisfying catchments, and the ratio of DCL occurrence. In cases in which three criteria were satisfied, the occurrence ratio of an earthquake-induced DCL was 0.5 when the distance was $\leq 4 \mathrm{~km}, 0.31$ when the distance was 4 to $8 \mathrm{~km}$, and 0.5 when the distance was 8 to $12 \mathrm{~km}$. There was a clearly discernible relationship between the DCL occurrence ratio in a catchment that satisfied two criteria, and distance from a fault; that in a catchment that satisfied no or only one criterion, when the distance from the fault was $\leq 4 \mathrm{~km}$, tended to be lower than that in a catchment that satisfied two or three criteria, when the distance from the fault was greater than $4 \mathrm{~km}$. This means that the relationship between the number of satisfied criteria and the probability of DCL does not depend on the distance from a fault.

\section{CONCLUSION}

This study compared pre-earthquake susceptibility to DCLs and distribution of landslides caused by the Iwate-Miyagi Inland Earthquake of 2008 at a catchment scale [Uchida et al., 2011]. We used the assessment method proposed by Uchida et al. [2011], which independently identified as highly susceptible those catchments that were affected by DCLs due to the Iwate-Miyagi Inland Earthquake of 2008. We concluded that the method is useful for assessing susceptibility to both heavy rain-induced and earthquake-induced DCLs. However, in some areas close to seismically active faults, DCLs occurred in catchments that were identified as low-susceptibility areas. This indicates that the method is less accurate in areas with very strong ground motion. 


\section{REFERENCES}

Carro. M., Amicisb. De. M, Luzic. L. and Marzorati. S. (2003): The application of predictive modeling techniques to landslides induced by earthquakes: the case study of the 26 September 1997 Umbria-Marche earthquake (Italy), Engineering geology, Vol. 69, pp. 139-159.

Chigira. M. (2006): Prediction of potential landslide sites -from the viewpoint of geology and geomorphology-, Journal of Geotechnical Engineering (C), Vol. 62, No. 4, pp. 380-381 (In Japanese).

Earthquake spectra. (2001): Chi-Chi, Taiwan, Earthquake of September 21, 1999 Reconnaissance Report, Supplement a to Vol. 17, pp. 61-76.

Geli, L., Pierre, Y, B. And Beatrice, J. (1988): The effect of topography on earthquake ground motion: a review and new results, bulletin of seismological society of America, Vol. 78, No. 1, pp. 42-63.

Harp. L. E. and Jibson. W. R. (1996): Landslides triggered by the 1994 Northridge, California, earthquake, Bulletin of the Seismological Society of America, Vol. 86, pp. S319-S332.

Hayashi. S., Araki. T., Yamada. T. and Numamoto. S. (2010): Factors of slope failures triggered by the Noto-Hanto Earthquake in 2007, Journal of the Japan Society of Erosion Control Engineering, Vol. 63, No. 3, pp. 19-26 (in Japanese).

Iwahashi. J., Kamiya. I. and Yamagishi. H. (2009): Estimation of the Most Suitable Window Size of the Slope Gradient and Convexo Concave Index for the Assessment of Shallow Landslides Using High Resolution LiDAR DEM, Japanese Geomorphological union, Vol. 30, No. 1, pp. 15-27 (in Japanese).

Jibson, R.W. (2007): Regression models for estimating coseismic landslide displacement. Engineering Geology, Vol. 91, pp. 209-218.

Kang.T. C., Shou.H.C. and Mei.L.H. (2007): Modeling typhoon- and earthquake-induced landslides in a mountainous watershed using logistic regression, Geomorphology, Vol. 89, pp. 335-347.

Keefer, D.K. (1984): Landslides caused by earthquakes. Bulletin of the Geological Society of America, Vol. 95, pp. 406-421.

Lee, C, T., Huang, C, C., Lee, J, F., Pan, K, L., Lin, M, L., Dong, J, J. (2008): Statistical approach to earthquake-induced landslide susceptibility, Engineering Geology, Vol. 100, pp. 43-58.

Lee, S., Evangelista, D. G. (2006): Earthquake-induced landslide-susceptibility mapping using an artificial neural network, Natural Hazard and Earth System Sciences, Vol. 6, pp. 687-695.

Mankelow. M J. and Murphy. W. (1998): Using GIS in the probabilistic assessment of earthquake triggered landslide hazard, Journal of Earthquake Engineering, Vol. 2, No. 4, pp. 593-623.

Meunier, P., Hovius, N. and Haines, A. J. (2007): Regional patterns of earthquake-triggered landslides and their relation to ground motion, Geophys. Res. Lett., Vol. 34, pp. L20408 10.1029/2007GL031337.
Meunier, P., Hovius, N. and Haines, A. J. (2008): Topographic site effects and the location of earthquake induced landslides, Earth and Planetary Science Letters, Vol. 275, pp. 221-232.

Miles. B. S. and Keefer, D.K. (2009): Evaluation of CAMEL comprehensive areal model of earthquake-induced landslides, Engineering Geology, Vol. 104, pp. 1-15.

National Institute of Advanced Industrial Science and Technology. (2010): Seamless geological map of Japan (1:200,000).

O'Callaghan, J.F., and Mark, D.M. (1984): The extraction of drainage networks from digital elevation data, Comput. Vision Graphics Image Process., Vol. 28, pp. 328- 344.

Okimura. T., Ichikawa. R. And Fujii, I. (1985): Methods to predict failures on granite mountain slopes by a infiltrated water movement model in a surface layer, Journal of the Japan Society of Erosion Control Engineering, Vol. 38, No. 5, pp. 4-13.

Ou, G, Q., Pan, H, L., Liu, J, F., Fan, J, R and You, Y. (2010): Characteristics of Sediment-Related Disasters Triggered by the Wenchuan Earthquake, International Journal of Erosion Control Engineering, Vol. 3, No. 1, pp. 59-68.

Saito. M., Araya. T. and Nakamura. F. (1995): Sediment Production and Storage Processes Associated with Earthquake-induced Landslides in Okushiri Island, 1993, Japan Society of Erosion Control Engineering, Vol. 47, No. 6, pp. 28-33 (in Japanese).

Suzuki, R., Kurihara, J., Sakurai, W., and Sakai, N. (2007): Characteristics and an extraction method of deep landslide prone area occurred by heavy rainfall, Civil Engineering Journal, Vol. 49, No. 5, pp. 58-63 (in Japanese).

Takaya, S., and Suzuki, K. (2007): Huge mountain failure caused by Typhoon No. 14 in Miyazaki Prefecture in 2005, Journal of the Japan Landslide Society, Vol. 44, No. 2, pp. 20-26 (in Japanese).

Tamura. K.., Uchida. T., Suzuki. R. and Matsumoto. N. (2009): Discussion on the occurrence mechanism of deep catastrophic landslide induced by heavy rainfall, Proceeding of Japan Society and Erosion Control Engineering, pp. 380-381 (In Japanese).

The Geospatial Information Authority of Japan. (2008): Diastrophism caused by the Iwate \& Miyagi inland earthquake in 2008 (No.2 report), http://www.gsi.go.jp/common/000043769.pdf (in Japanese).

Uchida T, Osanai N, Onoda S, Takayama T, Tomura K. (2006): A simple method of producing probabilitic seismic shallow landslide hazard, Interpraevent Int. Symp, Niigata 2006, Disaster mitigation of debris flow, slope failures and landslides, vol. 2, Universal Academy Press, Tokyo, pp. 529-534.

Uchida, T., Yokoyama, O., Suzuki, R., Tamura, K. and Ishiduka, T. (2011): A New Method for Assessing Deep Catastrophic Landslide Susceptibility, International Journal of Erosion Control Engineering, Vol. 4, No. 2, pp. 32-42.

Wang. N. W., Chigira. M, and Furuya. T. (2003): Geological and geomorphological precursors of the Chiu-fen-erh-shan landslide triggered by the Chi-chi earthquake in central Taiwan, Engineering Geology, Vol. 69, pp. 1-13. 
Wilson, R.C., Keefer, D.K. (1985): Predicting a real limits of earthquake-induced landsliding. U.S. Geological Survey Professional Paper, Vol. 1360, pp. 317-345.

Yagi, H., Sato, G., Higaki, D., Yamamoto, M, and Yamasaki, T. (2009): Distribution and characteristics of landslides induced by the Iwate-Miyagi Nairiku Earthquake in 2008 in Tohoku District, Northeast Japan, Landslides, Vol. 6, No.
4, pp. 335-344.

Yokoyama, O., Uchida, T., Tamura, K., Suzuki, R., and Inoue, T. (2011): Relationship between catastrophic landslide and geomorphological and geological features in Mt. Wanitsuka, Miyazaki Prefecture, Journal of the Japan Society of Erosion Control Engineering, Vol. 63, No. 5, pp. 3-13 (in Japanese). 